\title{
THE JEPARA CHAIRS BASED ON THEIR STYLE AND PERIOD
}

\author{
Octaviana S.C. Rombe ${ }^{1}$; Yunida Sofiana ${ }^{2}$; \\ Bambang Kartono Kurniawan ${ }^{3}$; Oktavianus Marti Nangoy ${ }^{4}$ \\ ${ }^{1,2,3,4}$ Desain Interior Department, School of Design, Bina Nusantara University \\ Jl. K.H. Syahdan No. 9 Palmerah, Jakarta Barat, 11480 \\ 10ctavianar@gmail.com; ${ }^{2}$ syunida@gmail.com; ${ }^{3}$ kartono.bambang@gmail.com; ${ }^{4}$ ovinangoy@yahoo.co.id
}

\begin{abstract}
The purpose of this article was to identify the Jepara chairs based on its style and period. Qualitative research such as doing interviews with the Jepara chairs observer, observation to some centres and workshops of Jepara chairs, literature study from various books consisting the style and process of Jepara chairs production were conducted. The identification of Jepara chairs started with Islamic and Hinduism influence in the 16th to the 17th century when the missionary and sailor from Portuguese entered Java until the style of Jepara chair in the 20th century. The alteration that mirrors the changes in socio-cultural aspect was being analysed as the style foundation that was used periodically in the making of the Jepara chairs. The categories a chair to have a Jepara style is a chair made by the craftsman in Jepara that, includes local factors both technically and material based that is combined with foreign culture, religion, and designs that brought at the time the chairs have been made. This research finds that chairs with Jepara style are a combination of the international world with a glimpse of local wisdom, with a touch of the maker's personality that makes it unique and a bit different with its origin style.
\end{abstract}

Keywords: Jepara chair, style, design, Jepara, Indonesian furniture

\section{INTRODUCTION}

Jepara, Central Java, is well known as the centre of wood furniture both locally and internationally. The craftsmanship that inherited from generation to generation has become part of the Jepara people's lives. But recently this craftsmanship has slowly begun to fade. The Jepara furniture industry has been through an industrial transformation at 1997 until 2006 (Kurniawan, 2008). The past success of Jepara furniture industry is yet to be felt again until now.

It is very unfortunate if the furniture products of Jepara are not identified immediately and placed in the Indonesian furniture map, or even on an international scale. In this research, we aim to identify Jepara's furniture works gradually starting from the chairs. Jepara produces various type of chairs, and it is considered to be one of their prominent works. That is why we are doing the research about their chairs. We aim to turn the Jepara furniture works become a source of literature information not only for the furniture industry but also for interior design and the art education in Indonesia.

Formulation problems of the research are: (1) When the chairs are manufactured in Jepara? (2) What are the styles that existed in the history of Jepara chairs manufacturing? (3) What are the differences of the Jepara chairs based on its period? (4) What are the factors that influence the style of Jepara chairs in a certain period? Besides that, the area of the problem in this research will only cover about the style of the Jepara chairs and the period that the Jepara chairs are manufactured. 
Based on the history development of Jepara chairs since the 6th to the 20th century, Jepara sculpture has developed that heavily influenced by various beliefs, cultures, and styles. It turns into numerous products, ornaments, decorations, carving techniques, and designs. Due to its several results, grouping was necessary as it helps to identify different types of furniture along with its style to use it as a reference.

This research begins with the identification of the chairs that has been assimilated and profoundly influenced by arts. The purpose of this research is to identify the Jepara chairs based on its style and period. In researcher's thesis, according to Henk Baren (as cited in Joko Sukiman, 2000), Jepara chairs' style has four different interpretation, they are: (1) Objective style (objektif stijl) is a style that is possessed by itself. (2) Subjective style (subjective stjil) or persoonlijke stijl is the artist's style to show their credibility. (3) Massa Style (Nationale stijl) is a style that represents a nation or certrain group. (4) Technical Style (technische stijl) focuses on the speciality of techniques, matters, or any materials used.

The style analysis of Jepara chairs in this research will be further reviewed by firstly using the objective style and Massa style. As far as the literature review that we are currently doing, the styles that are identified such as (1) Style that represents a certain religious group as to this case is Islam. The ornament such as floral, geometric, stiliran or the star motives that disguised by the coral reef on the artifacts. It is found in the Mantingan Mosque located in Jepara. (2) The style that represents the immigrant such as Portuguese, Dutch, and Chinese. The Jepara chairs possess fusion style elements from Europe in the 17th to the 19th century. The variety of bubutan and ulir decorations are one of an example of Portuguese influence in Jepara's motive. While the foot shape of horsehooffeet and elephant-trunk leg that shapes like an animal's claw, symbolizes the Chinese influence. On the other hand, as a sign of European influence, the effect on the chippendale style which is very popular in England. (Kurniawan, 2008). (3) The style that represents a certain group of genre, such as classic, modern, and post-modern. The work of a group of young Indonesian designers whose work is wellknown through exhibitions and international competition.

\section{METHODS}

The researchers are aiming to do various types of research through the qualitative method by interviewing the Jepara chairs' observer, doing the observation to some centres and workshops in Jepara, and doing a literature study from various books that discuss styles and the process of making the Jepara chairs. The analysis of the Jepara chairs will be further reviewed for its style and period objectively. In addition, the review will be put into certain style groups based on its mass. Finally, the data will further classify based on its period.

For the research, there will be two types of data; they are primary and secondary data. The primary data will obtain through several visits to the Jepara chairs manufacture centres. In the location, an interview with the Jepara chairs observer will be held. While the secondary data will be pursued through books that discuss Jepara chairs and chairs that inspired by the Jepara styles.

The data will be analyzed objectively based on its style and mass, and then it will be put into certain groups. After that, the year of the matter is crafted will be used to analyze further the Jepara chairs. Whilst analyzing the period of the chairs are made, the researchers also aim to identify certain traits that present while crafting the matters, as well as factors that differs the Jepara chairs style from time to time. When the identification process is done, then it will be the time to decide from which area of the Indonesian furniture map the Jepara chairs will be placed globally. The Indonesian furniture map will hold a significant role in further analysis, that is why the process of setting the Jepara chairs on the map is crucial. 


\section{RESULTS AND DISCUSSIONS}

Based on the period influence of the chairs manufacture, the style of the Jepara chairs can be listed as the style of the Jepara chairs before XIX century and the style of Jepara chair in the XIX century. The styles of the Jepara chairs before XIX century are the style at 16th century that has religion influences, the style at the 17th century that has influence of baroque art, Louis XIV, Louis $\mathrm{XV}$, and Louise XVI, and the style of the 18th century that has the influence of Rococo and England. While the styles of Jepara chairs in the XIX century have the influence of R.A. Kartini and form of follow function and less is more styles.

The style of Jepara chairs at the 16th century has some influences. First is religion influences. In the government of Queen Kalinyamat, a significant documentation is never been found. Based on the data available, carving patterns are the element of a decent design of buildings as well as home furnishings including chairs. There are two significant religions influence the style development of the Jepara chairs. First, the influence of Hinduism in the carving patterns in Jepara such as lotus, kala form, and makara form along with geometrical meander and swastika motive (Gustami, 2000). The second one is the Islamic influence in the carving pattern in Jepara such as vine tendrils, growing plant, flowers, and fruits (Gustami, 2000)

Other than carving patterns, the variety usage of rattan is also a style invented in the 16th century. As a result of these influences, this style is categorized into the classic-traditional style, as shown in Figure 1, 2, 3, 4, 5, and 6.

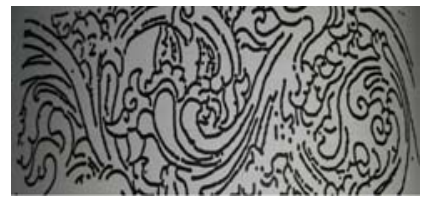

Figure 1 Jepara Carving Patterns of Growing Plants that Influenced by Hinduism in the Kalasan Temple (Source: Gustami, 2000)

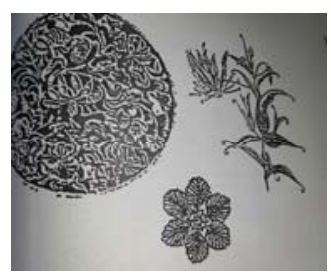

Figure 3 Jepara Carving Pattern Stilasi Plants After Islamic Influence in Mantingan Mosque

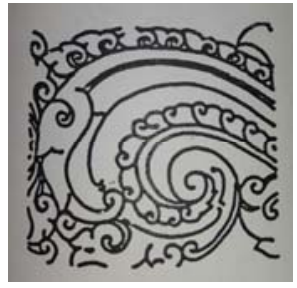

Figure 2 Jepara Carving Patterns Adaptation After Islamic Influence

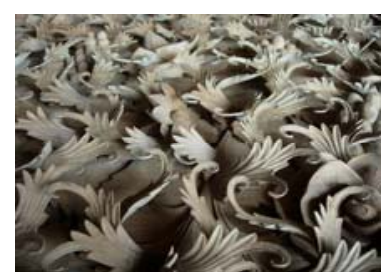

Figure 4 Jepara Carving Pattern Adapted from Hinduism and Islamic Influence (Source: Deny Willy, www.apikayu.files.wordpress.com) 


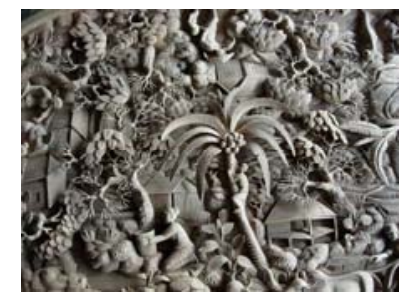

Figure 5 Jepara Carving Pattern Portrays the Daily Life of the Society in Jepara

(Source: Andar Bagus, www.apikayu.wordpress.com/tag/pengrajin-ukirindonesia)

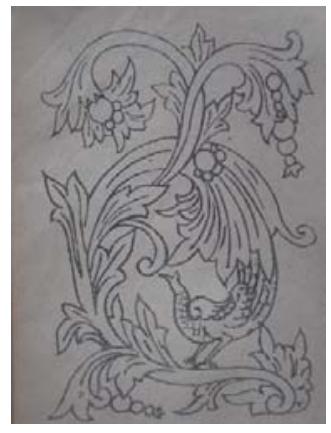

Figure 6 An Example of Jepara Carving Pattern (Source:

http://artkimianto.blogspot.co.id/2009/11/ukiranmotif-jepara.html)

In general, the characteristics of Jepara's carving pattern are possessing leafs carving in a shape of triangle and slope. Flowers or fruits with circular form are normally found on every edge of the leaf. The circular shape usually comes with many shapes. Besides, it is typically larger in the beginning and narrows down to the edge. There can also be seen flowers or fruits in large circular forms surrounded by little circles. The main leaf motive possesses organic and rounded complexion. Leafs can always be found on every edge of the carving. The surfaces of the leaf carvings are in the shape of the triangular prism.

While the Jepara floral and fruit motives are in the convex shaped as it mimics grapes or Wuni fruit that are arranged in a row or cluster. The flowers are often found in the corner of the carving where the primary leaf existed or where the carving is surrounded by leafs with the flowers mimicking the shape of the leaf. In the leaf-carving fragment, three line fragments follow the direction of a leaf that forms like a light. The Jepara carving motives are usually not deeply carved. In fact, it is often made with the translucent base, and the carving is often referred as Krawangan or translucent base carving. Jepara carving motives are often used to decorate handicraft goods including the head rest in Jepara chairs (Kimianto, 2009).

The style of the 17th century that has the influence of baroque art, Louis XIV, Louis XV, and Louis XVI. In Baroque art influence, the baroque genre on European chairs adapted from the craftsman in Jepara. According to Boyce (2014), the Baroque characteristic of chairs is such as solid composition along with a dramatic symmetrical shape. Also, based on Marizar (2003), this style uses a lot of dent and edge lines. The prominent element of design on the Jepara chairs with touch the Baroque style is the strength of the motive that sets a luxurious impression. The application of Jepara motive is traced in detail by using the complicated three-dimensional carving techniques. The straight figure is not really necessary in Jepara style, as seen in Figure 7 and 8. 


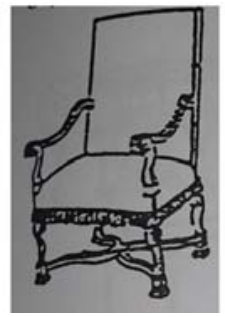

Figure 7 An Example of a Chair that Has Influence of Baroque Style

(Source: Gustami, 2000)

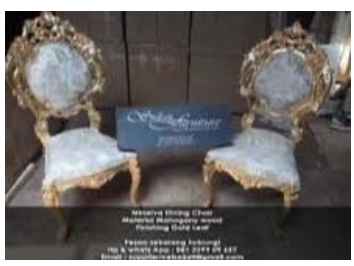

Figure 8 An Example of a Jepara Chair with a Complicated Tendril Motive and Lavish Adaptation of the Baroque Style (Source: www.sultanfiurniture.com)

While the style of Louis XIV chair is another version of the Baroque style with French influence. Louis XIV style of chairs has a classy and expensive characteristic with a symmetrical shape and big scale. The usage of decoration motive with a clear decorative limit, dark colors, thick shape, and the firm line becomes the characteristic of Louis XIV style. This kind of chair can be seen in Figure 9.

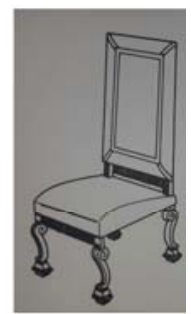

Figure 9 Louis XIV Chair

(Source: Boyce, 2014)

The style of Louis XIV chair is cited gently and is not taken as a whole. The characteristic of style Louis XIV chair is clear decorative border lines, heavy shape, and firm lines. It is adapted to this chair with a touch of a simple Jepara carving motive and a combination of the foot style from Louis XIV with leaf motive on the base of the foot. This kind of chair can be seen in Figure 10.

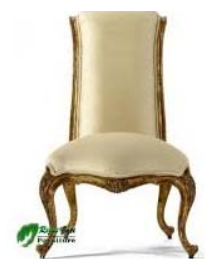

Figure 10 Jepara Chair with Louis XIV Style

(Source: www.decorcamp.com)

It is also different in the style of Louis XV chair. The style of Louis XV is known as the Rococo Revival (Boyce, 2014). The popular motive that can be seen in this style is the floral motive with bright and pale color, for instance, sea green, pale blue and pale yellow, lilac, and white with a touch of gold. The picture of this style can be seen in Figure 11. 


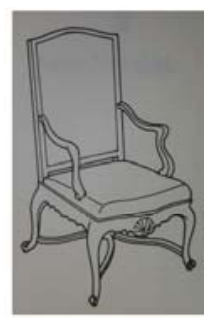

Figure 11 The Chair with Influence of Louis XV

(Source: Boyce, 2014)

Jepara chairs adapt to the style chair of Louis XV. These chairs have a characteristic of Jepara floral motive in the center of the footing framework and the seat's rest framework with the application of local rattan material. This kind of chair can be seen in Figure 12.

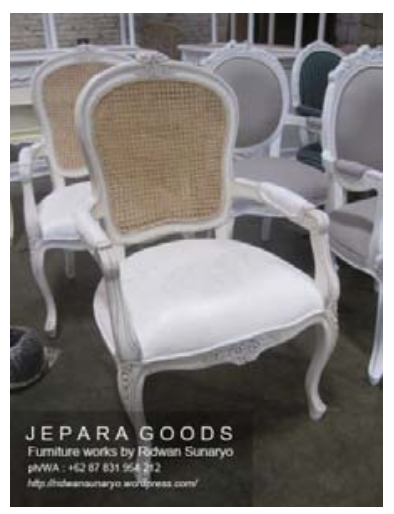

Figure 12 Jepara Chair with Louis XV Style

(Source: www.Jeparagoods.com)

Another influence of the Jepara chairs comes from Louise XVI. It is also known as Neoclassical with an accentuation on straight lines, symmetrical shape with the usage of decorative motive with a classic style (Boyce, 2014). This style of chair is not fond of any dents (Marizar, 2003). Figure 13 is the example of chair with an influence of Louise XVI.

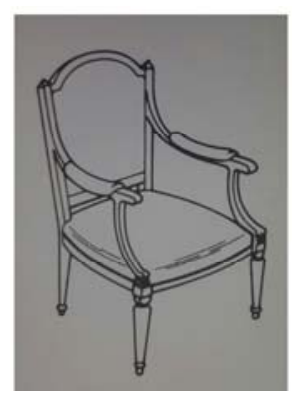

Figure 13 Chair with an influence of Louise XVI

(Source: Boyce, 2014) 
The Jepara chairs with influenced of Louise XVI is more simple in details and still combine of dents that leave more gentle look. The characteristic of Jepara is shown in its upper foot, the meeting between foot and hands of the chair. This chair adapts the floral Jepara motive, as seen in Figure 14.

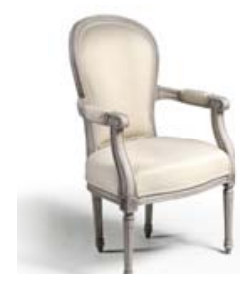

Figure 14 Jepara Chair with Influence of Louis XVI style (Source: www.JualMebelJepara.com)

In the 18th century, the style of Jepara chairs gets influence from Rococo and England. The Rococo style was born as the resistance of the Baroque style that is formal and luxurious. This style gives priority to the convenience factor. It is the modification from Louis XIV style and the development of neo-classic style. The decorative motive used are corals and flowers (Boyce, 2014).

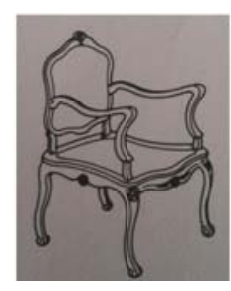

Figure 15 Rococo Style (Source: Вoyce, 2014)

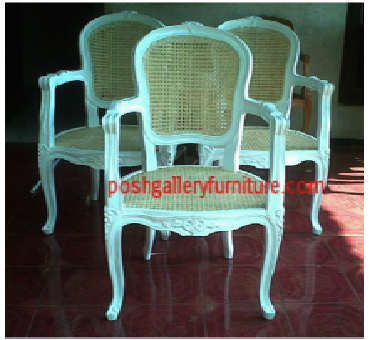

Figure 16 The Adaptation of Rococo Style in Jepara Chair with Floral Motive (Source: www.poshgalleryfurniture.com)

Another influence to Jepara chairs in the 18th century is England influence. The Regency style is a neo-classical style. It is an eclectic mixture of various forms and elements of decorations originated from Greece, Rome, and Egypt, contemporary French until the Chinese culture (Boyce, 2014). This kind of style can be seen in Figure 17 and 18.

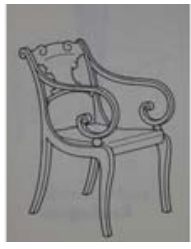

Figure 17 The Regency Chair (Boyce, 2014)

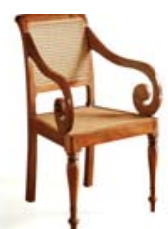

Figure 18 The Adaptation of Regency Chair in Jepara Chair

(Source: www.indonesia.indofur.com) 
In Figure 18 above, the Regency style is made with a touch of local wood material (rattan and mahogany). While the picture below is the Regency style is being adapted with a bit of local wood material, such as mahogany and rattan with a Jepara carving pattern on the part of the seat's rest.

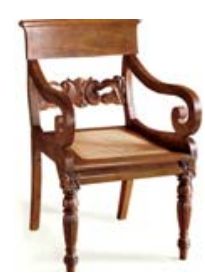

Figure 19 The Adaptation of Regency Style in Jepara Chair (Source: www.indonesia.indofur.com)

The Jepara chair style in the XIX century gets influence from R.A. Kartini and Form Follow Function and Less is More styles. Jepara chairs that get influence from R.A. Kartini happens in 1920. At that time, R.A.Kartini receives an order of box and tube made of Sonokeling wood from the Netherland (Gustami, 2000). This order is the beginning of Jepara furniture trading that Kartini sends to Europe. Most of the goods that sent by Kartini herself because Kartini is not only competent in writing, but she is also good with drawing. The decorative pattern that she designed is known as Lunglungan Bunga and referred as the original decorative pattern of Jepara (Sachari, 2006). The picture of Lunglungan Bunga can be seen in Figure 20.

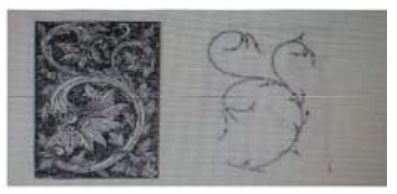

Figure 20 Carving pattern of Lulungan Bunga

(Source: http://119.252.174.21/indikasi-geografis/filemedia/Buku-Persyaratan-Mebel-Ukir-Jepara-

Perubahan1/mobile/index.html\#p=18)
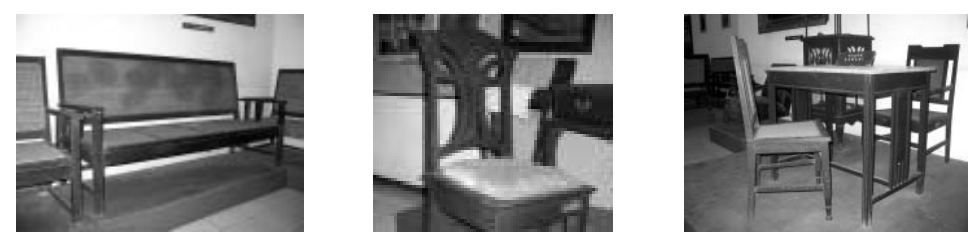

Figure 21 The Furnitures that Produced in the R.A. Kartini Era

Furniture from Figure 21 are predicted to be R.A. Kartini’s idea. The clean and firm design show the influence of Form Follows Function style that R.A. Kartini might be aware of as she has a good international knowledge (Sachari, 2006). Besides, there are pictures below that believed R.A. Kartini designed it. 

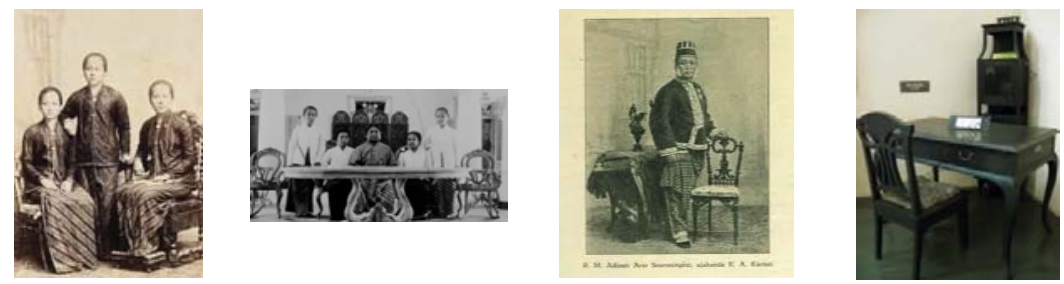

Figure 22 Documentations of R.A.Kartini’s Chair Design in Her Era (Source: www.museumindonesia.com/museum/212/museum_R.A._Kartini)

Besides that, in the 18th century, the influence of using bending wood in making a chair is started. Michael Thonet firstly introduces it approximately in the 1830s. This influence is one of the symbols from the beginning of the style that adhere the Form Follow Function and Less is More style. This style is introduced by some designers such as Mies Van Der Rohe and Le Corbusier. (Boyce, 2014), as seen in Figure 22.

The high market demand for the chair in this style, finally make the way to the centre of furniture in Jepara. Due to the limitation of technology, this style is being adapted by not using the bending system as a whole but by using a combination of carving that is mastered by most of the chair craftsman in Jepara. The materials used are also adapted by using the local material such as teak, mahogany, and rattan, as shows in Figure 23 and 24.

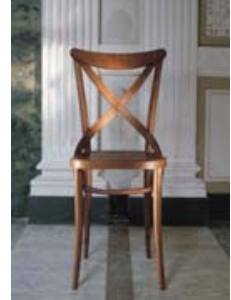

Figure 23 Thonet Chair designed by Furniture Maker from German by Doing the Bending Procress (Source: www.swiveluk.com)

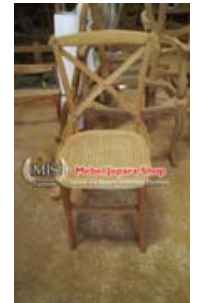

Figure 24 Thonet Chair with Jepara Style by Using Carved Teak Wood and Foot and Seated from Rattan (Source: www.mebeljeparashop.com)

Entering 20th century, the market demand of high quality handmade furniture decreases. The low-cost production and the development of industrial mass furniture especially from China becomes the reason of it. It makes the Jepara chair to lose its style. The production of Jepara chairs only meet the quantity target while increasingly losing its identity. The craftsmanship that every craftsman possessed were not appreciated as much when it comes to producing wood. The workshops that normally produce Jepara chairs are closed and . The other workshops are no longer producing Jepara chairs and shifting to other types of furniture that only rely on machines and use metal instead of wood. Jepara chair at the beginning of this century adapts the Less is More and Form Follows Function concept that simply known as Minimalist style, as seen in Figure 25 and 26. 


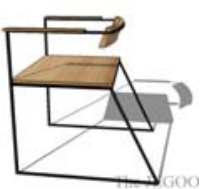

Figure 25 The Adaptation of Jepara chair from Form Follow Function and Less is More Concept with the Combination of Metal

(Source: www.ridwansunaryo.wordpress.com)

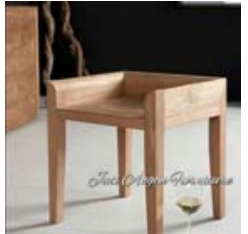

Figure 26 The Adaptation of Jepara Chair fromForm Follows Function and Less is More Concept with Simply Rounded Carving at the Top of Hand Rest (Source: www.growstaweb.com)

\section{CONCLUSIONS}

Chairs made in Jepara do not always qualify as Jepara style. The categories of a chair that have a Jepara style is a chair that is made from the craftsman in Jepara. It includes local factors both technically and material based that is combined with foreign culture, religion, and designs that brought at the time the chairs have been made. Chairs that are crafted with a Jepara style is a combination of an international style with a touch of local wisdom, as well as the designer's signature style. The combination makes it unique and different from their origin.

The local wisdom that included in the Jepara chair is the usage of local material such as woods that can be found in Jepara and rattan that can be found in Indonesia along with going through manual production by using the Indonesian rich wooden crafttechnique. It will be very difficult to include Jepara in a category based on its style and period according to the international timeline. It because of remembering the touch of personalization and adaptation in the market from every level that makes the Jepara chairs more of an eclectic from many styles with a touch of local material and craftsmanship.

The existence of chair with a Jepara style is a precious heritage for the world of Indonesia artist, as well as Internationally. We want to encourage people highly to conserve the transfer craftsmanship in the workshop, documentation, or socializing the younger generation. So that, the Jepara style with its local craftsmanship will be preserved and kept up with the new trends.

\section{REFERENCES}

Boyce, C. (2014). Dictionary of Furniture ( $3^{\text {rd }}$ Ed). Skyhorse Publishing: New York.

Gustami, S. P. (2000). Seni Kerajinan Mebel Ukir Jepara. Kanisius: Jakarta.

Kimianto, E. (2009). Ukiran Motif Jepara. Retrieved December $20^{\text {th }} 2015$ from www.artkimianto.blogspot.co.id/2009/11/ukiran-motif-jepara.html

Kurniawan, B. K. (2008). Daya Tahan Industri Mebel Ukir Jepara di Tengah Gejolak Perubahan Sosial Dan Budaya Kurun Waktu 1997-2006 (Master's thesis). Available from Perpustakaan UGM, Yogyakarta.

Marizar, E. S. (2003). Mebel Klasik. Gamma Pustaka: Tangerang. 
Sachari, A. (2006). Pergeseran Gaya Pada Desain Furniture Indonesia Abad Ke 20 Studi Mengenai Pemberdayaan Nilai Estetis Menghadapi Keterbukaan Budaya. Dimensi Interior, 4(1), 9-16.

Sukiman, J. (2000). Kebudayaan Indis dan Gaya Hidup Masyarakat Pendukungnya di Jawa. Yayasan Bentang Budaya: Yogyakarta. 